\title{
Long-term effectiveness of Tension-Free Vaginal Tape (TVT) procedure - twelve years after surgery
}

\author{
MAGDALENA BROŚ-KONOPIELKO ${ }^{1, \mathrm{~A}, \mathrm{~B}, \mathrm{D}-\mathrm{F}}$, GRZEGORZ CHMIELEWSKI ${ }^{1, \mathrm{~B}}$, AGNIESZKA JODZIS ${ }^{1, \mathrm{~B}}$, \\ JUSTYNA TELIGA-CZAJKOWSKA ${ }^{2, E}$, KRZYSZTOF CZAJKOWSKI ${ }^{1, A, C, D}$
}

${ }^{1}$ The $2^{\text {nd }}$ Department of Obstetrics and Gynaecology, Medical University of Warsaw, Poland

${ }^{2}$ Department of Obstetrics and Gynaecology, Didactics Medical University of Warsaw, Poland

A - Study Design, B - Data Collection, C - Statistical Analysis, D - Data Interpretation, E - Manuscript Preparation, F - Literature Search, G - Funds Collection

Summary Background. Urinary incontinence is defined as any involuntary loss of urine. The TVT (Tension-Free Vaginal Tape) operation is a treatment for stress urinary incontinence introduced in Poland in the year 2000 . There are few studies evaluating the long-term effectiveness of TVT in Polish women.

Objectives. To evaluate the long-term effectiveness of TVT in the treatment of stress urinary incontinence in women.

Material and methods. 40 women operated on in the period 1999-2004 were recalled $12.6 \pm 1.2$ years after TVT for a follow-up study. 85 vs $15 \%$ of women were operated on due to primary vs recurrent stress incontinence, respectively. 20 vs $80 \%$ of the patients had mixed vs pure stress urinary incontinence, respectively. The effectiveness of TVT operations was assessed objectively on the basis of a cough test, and subjectively on improvement after treatment according to the patients' answers (yes/no), PGI-I, PSQ and VAS (,„0“ was the total absence of improvement after surgery, „100“ - total improvement).

Results. The cough test was negative in $85 \%$ of cases. Subjectively, $85 \%$ of women declared improvement after TVT. Based on PGI-I $-77.5 \%$ of them maintained improvement after surgery. Based on PSQ $-70 \%$ of the women assessed control of urinary incontinence after surgery as better, $72.5 \%$ were satisfied with the results of the operation, and $77.5 \%$ of them would recommend TVT to other women. Based on VAS, total improvement was noted by $12.5 \%$ of women, $60 \%$ of women rated improvement " $50-99$ ", and total lack of improvement was noted by $20 \%$ of the women.

Conclusions. TVT seems to be an effective form of treatment for urinary incontinence in women 12 years after surgery.

Key words: urinary incontinence, mid-urethral sling, TVT, effectiveness.

Broś-Konopielko M, Chmielewski G, Jodzis A, Teliga-Czajkowska J, Czajkowski K. Long-term effectiveness of Tension-Free Vaginal Tape (TVT) procedure - twelve years after surgery. Fam Med Prim Care Rev 2017; 19(3): 196-200, doi: https://doi.org/10.5114/ fmpcr.2017.69273.

\section{Background}

Urinary incontinence is a common condition among women of all ages [1]. Urinary incontinence is defined as any involuntary loss of urine [2]. Urinary symptoms affect different women in different ways and have variable influence on their physical, psychological, social, domestic and interpersonal lifestyle [1]. Among the most common types of urinary incontinence in women there are stress, urge and mixed (urge and stress) incontinence. Stress incontinence is the involuntary loss of urine with an increase in intra-abdominal pressure such as coughing, laughing, physical exercising, sneezing or sexual intercourse [3]. Urge incontinence is defined as involuntary loss of urine preceded by a sudden urge to void [1]. Symptoms of stress urinary incontinence increase with age and parity. Stress urinary incontinence is diagnosed with $0.5-20 \%$ of multiparae, and $15-60 \%$ of multiparae are affected by this condition [3]. Pregnancy itself, mode of delivery, oxytocin and prostaglandin use for induction of labour, and type of anesthaesia during the delivery have an impact on urinary incontinence [4]. The prevalence of urinary incontinence is nearly 4 times higher after vaginal delivery than after caesarean section (16.6\% vs 4.3\%) [5]. Urinary incontinence is associated with induction of labour with prostaglandins $(O R=1.74)[6]$. Epidural analgaesia during delivery is also a significant factor for later stress urinary incontinence surgery $(O R=0.82)$ [7]. Vaginal delivery has been strongly associated with a need of surgery for stress incontinence in the future [4]. Persson et al. [8] analysed a group of 10,074 women who underwent surgery for stress urinary incontinence. The risk increases with the parity - from OR = 3.57 after one delivery to $\mathrm{OR}=7.14$ after more than 3 deliveries [8]. Obesity has been shown to be a risk factor for stress incontinence [1]. There are data to suggest that chronic constipation may lead to urinary incontinence [1].

The symptoms of urinary incontinence radically impair psychological, somatic, and social functioning. Women's emotional state is affected, leading to a lowered quality of life [9].

Stress urinary incontinence is mainly treated surgically. Surgical treatment of stress urinary incontinence has been used for almost a century. More than one hundred operations for urinary incontinence have been described. Plastic surgery of the anterior vaginal wall was one of the most popular procedures. The procedure has lost its popularity due to the relatively high rate of recurrence of the condition, which proved that its long-term efficiency amounted to 67-82\% [3]. Afterwards, the Burch colposuspension was the most popular surgical procedure for the treatment of stress urinary incontinence until the team led by Professor Ulf Ulmsten introduced a new minimally invasive, ambulatory, standardized surgical procedure named Tension-Free Vaginal Tape (TVT) in Europe at the end of 1997 and in the USA at the end of 1998 [10]. The introduction of a mid-urethral retropubic sling like the TVT (Tension-Free Vaginal Tape) procedure has meant a significant step forward in the surgical treatment 
of stress urinary incontinence in women, mainly due to the low invasiveness and high postoperative efficacy [11]. Although the TVT procedure is minimally invasive, it is not free of complications. The most severe intra-operative complication is bladder or urethra perforation. The most common complications of sling procedures are: overactive bladder (OAB), voiding difficulties, urinary retention, pain, tape erosion and treatment failure [12].

Although in Poland the first such operations were performed around 2000, there has not been any long-term observation until now.

\section{Objectives}

The aim of the study was to evaluate the long-term (12year) effectiveness of TVT in the treatment of stress urinary incontinence in women.

\section{Material and methods}

The assessment was performed within an average period of $12.6 \pm 1.2$ years after TVT. Between the years 1999 and 2004, 240 women were operated on due to stress urinary incontinence by TVT in the $2^{\text {nd }}$ Department of Obstetrics and Gynecology of the Medical University of Warsaw. Each patient was examined before the operation gynaecologically and underwent a cough test in the lithotomy or standing position. All the operated on women had a positive cough and Bonney's tests before surgery. Before and after the operation, the patients filled in a diary of micturiation and a special urinary incontinence questionnaire. Prior to surgery, all patients had both general and culture urine analysis. They were operated on only in the presence of a sterile culture of urine. $85 \%$ of the women were operated on due to primary stress incontinence and $15 \%$ due to the recurring type. $20 \%$ of the operated on women had mixed (stress and urge) incontinence, and $80 \%$ had a pure urinary incontinence pattern. The average age of the women at the time of the treatment was $59 \pm 10.09$ years, while the control group was 71.9 \pm 10.09 years $(p=1.8)$. The BMI was $26.4 \pm 3.96$ before and $27.3 \pm 4.39$ after surgery $(p=0.3)$. A group of 150 women were contacted in 2015. Forty of those were referred for a series of follow-up visits, and after the signed informed consent had been obtained the patients were included in the study. After the operation each patient was examined gynaecologically and underwent a cough test in the lithotomy or standing position.

\begin{tabular}{|l|l|l|}
\hline \multicolumn{3}{|l|}{ Table 1. Material and methods } \\
\hline Data & Befor surgery & After surgery \\
\hline Age [years] & $59.0 \pm 10,09$ & $71,9 \pm 10,09$ \\
\hline BMI $\left[\mathrm{kg} / \mathrm{m}^{2}\right]$ & $26.4 \pm 3.96$ & $27.2 \pm 4.39$ \\
\hline POPQ & \multicolumn{2}{|l|}{} \\
\hline \multirow{2}{*}{$\begin{array}{l}\text { grade 0 } \\
\text { grade 1 } \\
\text { grade 2 }\end{array}$} & $100 \%$ & $82 \%$ \\
\cline { 2 - 3 } $\begin{array}{l}\text { primary stress } \\
\text { incontinence } \\
\text { recurrent stress } \\
\text { incontinence }\end{array}$ & 0 & $8 \%$ \\
\cline { 2 - 3 } \begin{tabular}{l} 
measurements \\
\cline { 2 - 3 }
\end{tabular} & $\begin{array}{l}\text { interview, diary of micturiation, urinary } \\
\text { incontinence questionnaire, gynaecologi- } \\
\text { cal examination, cough test }\end{array}$ \\
\cline { 2 - 3 } & $\begin{array}{l}\text { urinalysis } \\
\text { PGI-I, PSQ4, VAS }\end{array}$ \\
\hline
\end{tabular}

Objectively, the effectiveness of TVT operations was assessed on the basis of a cough test in the gynaecological and standing position. A positive test in at least one of the positions mentioned above accounted for ineffective treatment. Subjective improvement after treatment according to patients was assessed by answering the question "Do you feel any improvement after the treatment?". The Patient Global Impression of Improvement (PGI-I), the Patient Satisfaction Questionnaire (PSQ), and the $0-100 \%$ visual satisfaction scale (Visual Analogue Scale - VAS) were used also to assess patient satisfaction (Table 1). The study received the positive opinion of the Ethics Commission.

\section{Statistical analyses section}

The normal distribution of the data was checked using the Statgraphics Centurion Static Program Version XVII-X64. The data were reported as average values with standard deviation. The test of independence was calculated using the chi-square test ( $p<0.05$ was considered statistically significant).

\section{Results}

The cough test was negative in $85 \%$ of the women and positive in $15 \%$ of the women operated on with TVT (Table 2).

Table 2. Effectiveness of TVT operation in women with stress urinary incontinence 12 years after surgery (objective measurements)

Method Number of patients

\begin{tabular}{|l|l|l|l|}
\cline { 3 - 4 } \multicolumn{2}{c|}{} & $n$ & $\%$ \\
\hline \multirow{3}{*}{ Cough test } & negative & 34 & 85 \\
\cline { 2 - 4 } & positive & 6 & 15 \\
\hline
\end{tabular}

Subjectively (improvement after treatment according to patient's answer "Yes" or "No"), 83\% of the women declared improvement after the TVT surgery. In a more detailed analysis based on the PGI-I questionnaire $77.5 \%$ of the patients claimed improvement after surgery, of which $30 \%$ vs $30 \%$ vs $17.5 \%$ assessed the change after treatment as much better, better and slightly better. $10 \%$ of the operated on women reported changes for the worse. Based on the PSQ questionnaire, $70 \%$ of the women in the study assessed control of urinary incontinence after surgery as better, $72.5 \%$ were satisfied with the results of the operation, and $77.5 \%$ of the patients would recommend this form of treatment to other women. On the basis of the VAS, total improvement was noted by $12.5 \%$ of women, $60 \%$ of women rated improvement "50-99", and total lack of improvement was noted by $20 \%$ of the examined women (Table 3 ).

Table 3. Effectiveness of TVT operation in women with urinary incontinence 12 years after surgery (subjective measurements) Method

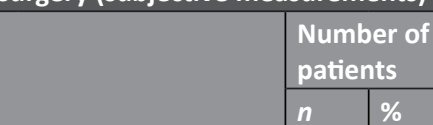

Improvement after treatment according to patients

Patient Global Impression of Improvement (PGI-I): overall impression of the patient change from pre-operation

Patient Satisfaction Questionnaire (PSQ): control of urinary incontinence after surgery

\begin{tabular}{|l|l|l|}
\hline yes & 33 & 83 \\
\hline no & 7 & 17 \\
\hline much better & 12 & 30 \\
\hline better & 12 & 30 \\
\hline a little better & 7 & 17.5 \\
\hline no change & 5 & 12.5 \\
\hline a little worse & 1 & 2.5 \\
\hline less & 1 & 2.5 \\
\hline much worse & 2 & 5 \\
\hline $\begin{array}{l}\text { extremely well } \\
\text { controlled }\end{array}$ & 2 & 5 \\
\hline well controlled & 15 & 37.5 \\
\hline slightly controlled & 11 & 27.5 \\
\hline no change & 1 & 2.5 \\
\hline $\begin{array}{l}\text { slightly out of } \\
\text { control }\end{array}$ & 2 & 5 \\
\hline poorly controlled & 8 & 20 \\
\hline not controlled at all & 1 & 2.5 \\
\hline
\end{tabular}




\begin{tabular}{|c|c|c|c|}
\hline \multicolumn{2}{|l|}{ Method } & \multicolumn{2}{|c|}{$\begin{array}{l}\text { Number of } \\
\text { patients }\end{array}$} \\
\hline & & $n$ & $\%$ \\
\hline \multirow{6}{*}{$\begin{array}{l}\text { Patient Satisfaction Ques- } \\
\text { tionnaire (PSQ): degree of } \\
\text { satisafction after the treat- } \\
\text { ment for urinary inconti- } \\
\text { nence }\end{array}$} & very satisfied & 5 & 12.5 \\
\hline & satisfied & 17 & 42.5 \\
\hline & a little satisfied & 7 & 17.5 \\
\hline & no change & 0 & 0 \\
\hline & a little dissatisfied & 1 & 2.5 \\
\hline & very dissatisfied & 2 & 5 \\
\hline \multirow{6}{*}{$\begin{array}{l}\text { Patient Satisfaction Ques- } \\
\text { tionnaire (PSQ): would the } \\
\text { patients recommend a TVT } \\
\text { operation to other people }\end{array}$} & $\begin{array}{l}\text { would strongly } \\
\text { recommend }\end{array}$ & 13 & 32.5 \\
\hline & recommend & 12 & 30 \\
\hline & $\begin{array}{l}\text { would probably } \\
\text { recommend }\end{array}$ & 6 & 15 \\
\hline & $\begin{array}{l}\text { probably would not } \\
\text { recommend }\end{array}$ & 3 & 7.5 \\
\hline & $\begin{array}{l}\text { would not recom- } \\
\text { mend }\end{array}$ & 3 & 7.5 \\
\hline & $\begin{array}{l}\text { would definitely not } \\
\text { recommend }\end{array}$ & 1 & 2.5 \\
\hline \multicolumn{4}{|l|}{$\begin{array}{l}\text { Visual Analogue Scale (VAS): } \\
\text { patient impression }\end{array}$} \\
\hline \multirow{4}{*}{$\begin{array}{l}0 \text { - total lack of improve- } \\
\text { ment after surgery } \\
100 \text { - total improvement }\end{array}$} & 0 & 8 & 20 \\
\hline & $1-49$ & 3 & 7.5 \\
\hline & 50-99 & 24 & 60 \\
\hline & 100 & 5 & 12.5 \\
\hline
\end{tabular}

We observed the presence of such late postoperative complications as painful gynaecological examination (3/40), vaginal erosion (3/40), bladder erosion (1/40), overactive bladder (OAB) de novo (4/40), reccurent urinary tract infection (8/40).

We assessed control of urinary incontinence after surgery based on PSQ according of various factors. The lack of positive cough test $(p=0.001)$, the absence of painful gynaecological ex- amination $(p=0.011)$, and bladder erosion $(p=0.002)$ had the greatest effect on improving urinary incontinence after surgery (Table 4)

\section{Discussion}

Urinary incontinence is defined by the International Continence Society as any uncontrolled urinary leak [2]. The incidence of this disease increases with age [2]. According to Polish studies, the incidence of incontinence in our operated on group of 59 -year-old women is high and amounts to $76 \%$. The most common form of urinary incontinence in this group is stress urinary incontinence [13]. The basic treatment for stress urinary incontinence is surgical procedures. More than 100 types of operation have been described, but since the last decade of the twentieth century, vaginal access has been most popular, with the placement of a polypropylene mesh under the central urethra. The mesh can be placed retropubically (e.g. TVT, I VS, SPARC), through the obturator foramen (e.g. Monarc, TVT-O), or exclusively from a single incision in the vagina (TVT-secure, MiniArc, Ajust) [14-16]. There are many studies evaluating the efficacy of TVT in the treatment of stress incontinence, also in comparison with other operations mentioned above. However, most of these studies assess the effectiveness of surgery after 1-7 years of follow-up. There are only a few studies analyzing the effectiveness of this method more than 10 years after the operation.

A cough test is considered an objective test showing whether a given procedure improves continence. Its execution is not standardized. It is performed in a litotomy and/or standing position, with various bladder filling (up to $150 \mathrm{ml}, 250 \mathrm{ml}, 300 \mathrm{ml}$ ) or with "bladder filled" $[4,6]$. Other authors performed a cough test during a urodynamic examination of the bladder filled up to a volume of $400-450 \mathrm{ml}$ [17]. In our study, the effectiveness of TVT operations was assessed on the basis of a cough test in both the gynaecological and standing position, with a "filled bladder" feeling reported by the patient. A positive test in at least one of the listed items was proof of ineffective treatment. The cough

\begin{tabular}{|c|c|c|c|c|c|c|c|c|}
\hline $\begin{array}{l}\text { Control of urinary in- } \\
\text { continence after surgery } \\
\text { Factor }\end{array}$ & $\begin{array}{l}\text { extremelly } \\
\text { well con- } \\
\text { trolled }\end{array}$ & $\begin{array}{l}\text { well con- } \\
\text { trolled }\end{array}$ & $\begin{array}{l}\text { slightly } \\
\text { controlled }\end{array}$ & no change & $\begin{array}{l}\text { slightly out } \\
\text { of control }\end{array}$ & $\begin{array}{l}\text { not con- } \\
\text { trolled at all }\end{array}$ & total & $\begin{array}{l}\text { chi- } \\
\text { square } \\
p\end{array}$ \\
\hline $\begin{array}{l}\text { Primary urinary } \\
\text { incontinence }\end{array}$ & 5 & 15 & 6 & 0 & 7 & 1 & 34 & \multirow[t]{2}{*}{0.124} \\
\hline $\begin{array}{l}\text { Secondary urinary } \\
\text { incontinence }\end{array}$ & 0 & 2 & 1 & 1 & 1 & 1 & 6 & \\
\hline $\begin{array}{l}\text { Positive cough test } \\
\text { after operation }\end{array}$ & 0 & 0 & 0 & 1 & 4 & 1 & 6 & \multirow[t]{2}{*}{0.001} \\
\hline $\begin{array}{l}\text { Negative cough test } \\
\text { after operation }\end{array}$ & 6 & 17 & 7 & 0 & 3 & 1 & 34 & \\
\hline $\begin{array}{l}\text { Painful gynaecological } \\
\text { examination }\end{array}$ & 0 & 0 & 0 & 0 & 3 & 0 & 3 & \multirow[t]{2}{*}{0.011} \\
\hline $\begin{array}{l}\text { Normal gynaecological } \\
\text { examination }\end{array}$ & 5 & 17 & 7 & 1 & 4 & 2 & 37 & \\
\hline Vaginal erosion & 0 & 1 & 0 & 0 & 1 & 0 & 2 & \multirow[t]{2}{*}{0.881} \\
\hline No vaginal erosion & 5 & 16 & 7 & 1 & 7 & 2 & 38 & \\
\hline Bladder erosion & 0 & 0 & 0 & 0 & 0 & 1 & 1 & \multirow[t]{2}{*}{0.002} \\
\hline No bladder erosion & 5 & 17 & 7 & 1 & 8 & 1 & 39 & \\
\hline OAB de novo & 0 & 2 & 1 & 0 & 1 & 0 & 4 & \multirow[t]{2}{*}{0.950} \\
\hline No OAB de novo & 5 & 15 & 6 & 1 & 7 & 2 & 36 & \\
\hline $\begin{array}{l}\text { Reccurent urinary tract } \\
\text { infection }\end{array}$ & 0 & 1 & 2 & 0 & 4 & 1 & 8 & \multirow[t]{2}{*}{0.089} \\
\hline $\begin{array}{l}\text { No reccurent urinary } \\
\text { tract infection }\end{array}$ & 5 & 16 & 5 & 1 & 4 & 1 & 32 & \\
\hline
\end{tabular}


test was negative in $85 \%$ of the analyzed women. Similar results were observed by Olsson et al. in their work [18]. 11.5 years after the operation the cough test was negative in $83.7 \%$ of the women surveyed [18]. In the study by Nilsson et al. [19] the cough test was negative in 95.35 women but it was performed in the lithotomy position, and on average 141 months after the procedure. Our study was performed on average 151 months after surgery. In the above mentioned Nilson et al. study, when the position during the cough test was changed, the results were slightly different $-90.2 \%$ of the women treated by TVT had a negative cough test in the standing position [19]. The lack of a positive cough test $(p=0.001)$ had the greatest effect on improving urinary incontinence after surgery in our study.

Liapis et al. [17] assessed objective efficacy on the basis of the pad test and standing cough test results. The one hour pad test was negative in $83 \%$ vs $80 \%$ of the operated on women 5 vs 7-years after operation, respectively [17]. Other objective methods of evaluating operations included a cough test during the gynaecological examination, which was also reported in our study.

The Patient urinary incontinence questionnaire, the Patient Global Impression of Improvement (PGI-I), the Patient Satisfaction Questionnaire (PSQ) and the 0-100\% Visual Analogue Scale (VAS) show the subjective efficacy of the tested procedure. Other researchers have also used similar methods in evaluating patient satisfaction in long-term follow-up after TVT [18]. Olsson et al.
[18] used the same questionnaire assessing urinary symptoms which was applied pre-operatively along with the visual analogue scale. The rate of subjective cure was $77 \% 11.5$ years after the operation [18]. In our study, the subjective improvement after the TVT procedure, depending on the method of assessement, reached the level of $85-70 \%, 12$ years after the operation.

Adams-Piper et al. [20] checked twenty-six patients who underwent a singleton delivery after placement of a mid-urethral sling. There were no MUS-related pregnancy complications, and the vaginal route of delivery had no negative impact on urinary continence [20]. In our study none of the women delivered after the TVT operation. Due to the fact that this procedure is performed in the case of younger women, it is important to know the long-term effectiveness of this type of surgery.

\section{Conclusions}

1. Long-term follow-up of TVT seems to prove the effectiveness of treatment for urinary incontinence in women.

2. The objective effectiveness of TVT is $85 \% 12$ years after surgery.

3. The subjective improvement after TVT, depending on the method of assessement, reaches the level of $83-70 \%$.

4. It should be noted that no more than $1 / 3$ of the women undergoing surgery were unsatisfied with its results.

Source of funding: This work was funded by the authors' resources. Conflict of interest: The authors declare no conflict of interests.

\section{References}

1. Cardozo L, Staskin D, eds. Textbook of female urology and urogynaecology. London: Martin Dunitz Ltd; 2002.

2. Ulmsten $\mathrm{U}$, Henriksson $\mathrm{L}$, Johnson $\mathrm{P}$, et al. An ambulatory surgical procedure under local anesthesia for treatment of female urinary incontinence. Int Urogynecol J 1996; 7(2): 81-86.

3. Stanek R, Kadziołka P, Stanek AM, et al. The use of synthetic materials in the treatment of stress urinary incontinence. Menopause Rev 2016; 15(2): 76-80, doi: https://doi.org/10.5114/pm.2016.61188.

4. Czajkowski K, Bros-Konopielko M. Pregnancy, vaginal delivery, oxytocin and prostaglandin for induction of labour, instrumental vaginal delivery (forceps, VE) and type of anesthesia and its factual impact on anatomy and function of pelvic floor. Arch Perinatal Med 2017; 23(1): 51-58.

5. Yang $\mathrm{X}$, Zhang HX, Yu HY, et al. The prevalence of faecal incontinence and urinary incontinence in primiparous postpartum Chinese women. Eur J Obstet Gynecol Reprod Biol 2010; 152(2): 214-217.

6. Pregazzi R, Sartore A, Troiano L, et al. Postpartum urinary symptoms: prevalence and risk factors. Eur J Obstet Gynecol Reprod Biol 2002; 103(2): 179-182.

7. Pretlove SJ, Thompson PJ, Toozs-Hobson PM, et al. Does the mode of delivery predispose women to anal incontinence in the first year postpartum? A comparative systematic review. Br J Obstet Gynaecol 2008; 115(4): 421-434.

8. Persson J, Wolner-Hanssen P, Rydhstroem H. Obstetric risk factors for stress urinary incontinence: a population-based study. Obstet Gynecol 2000; 96(3): 440-445.

9. Adamczuk J, Szymona-Palkowska K, Robak JM, et al. Coping with stress and quality of life in women with stress urinary incontinence. Prz Menopauzalny 2015; 14(3): 178-183, doi: https://doi.org/10.5114/pm.2015.54342.

10. Nilson CG. Creating a gold standard surgical procedure: the development and implementation of TVT. Int Urogynecol J 2015; 26(4): 467-469, doi: 10.1007/s00192-014-2616-2.

11. Abrams P, Cardozo L, Khoury S, et al. Incontinence $5^{\text {th }}$ International Consultation on Incontinence, February 2012, Paris, France [cited 10.05.2017]. Available from URL: https://www.ics.org/Publications/ICI_5/INCONTINENCE.pdf.

12. Fabian G, Kociszewski J, Kuszka A, et al. Vaginal excision of the sub-urethral sling: analysis of indications, safety and outcome. Arch Med Sci 2015; 11(5): 982-988, doi: https://doi.org/10.5114/aoms.2014.42305.

13. Bros-Konopielko M, Czajkowski K, Michalska B, et al. Występowanie nietrzymania moczu wśród polskich kobiet mieszkających w Warszawie. Fam Med Prim Care Rev 2007; 9(1): 22-25 (in Polish).

14. Mostafa A, Agur W, Abdel-All M, et al. A multicentre prospective randomised study of single-incision mini-sling (Ajust ${ }^{\circledR}$ ) versus tensionfree vaginal tape-obturator (TVT-O $\mathrm{T}^{\mathrm{M}}$ ) in the management of female stress urinary incontinence: pain profile and short-term outcomes. Eur J Obstet Gynecol Reprod Biol 2012; 165(1): 115-121.

15. Moore RD, Serels SR, Davila GW, et al. Minimally invasive treatment for female stress urinary incontinence (SUI): a review including TVT, TOT, and mini-sling. Surg Technol Int 2009; 18(2): 157-173.

16. Mostafa A, Lim CP, Hopper L, et al. Single-incision mini-slings versus standard midurethral slings in surgical management of female stress urinary incontinence: an updated systematic review and meta-analysis of effectiveness and complications Eur Urol 2014; 65(2): 402-427.

17. Liapis A, Bakas P, Creatsas G. Long-term efficacy of tension-free vaginal tape in the management of stress urinary incontinence in women: efficacy at 5-and 7-year follow-up. Int Urogynecol J 2008; 19(11): 1509-1512.

18. Olsson I, Abrahamsson AK, Kroon UB. Long-term efficacy of the tension-free vaginal tape procedure for the treatment of urinary incontinence. Int Urogynecol J 2010; 21(6): 679-683. 
19. Nilsson CG, Palva K, Rezapour M, et al. Eleven years prospective follow-up of the tension-free vaginal tape procedure for treatment of stress urinary incontinence. Int Urogynecol J 2008; 19(8): 1043-1047.

20. Adams-Piper E, Buono K, Withcomb E. A large retrospective series of pregnancy and delivery after midurethral sling for stress urinary incontinence. Female Pelvic Med Reconstr Surg 2016; 22(5): 307-310.

Tables: 4

Figures: 0

References: 20

Received: 15.05.2017

Revised: 09.06.2017

Accepted: 14.06.2017

Address for correspondence:

Magdalena Broś-Konopielko, MD, PhD

II Katedra i Klinika Położnictwa i Ginekologii WUM

ul. Karowa 2

00-315 Warszawa

Polska

Tel.: +48 22 596-64-21

E-mail: brosmagda@wp.pl 